
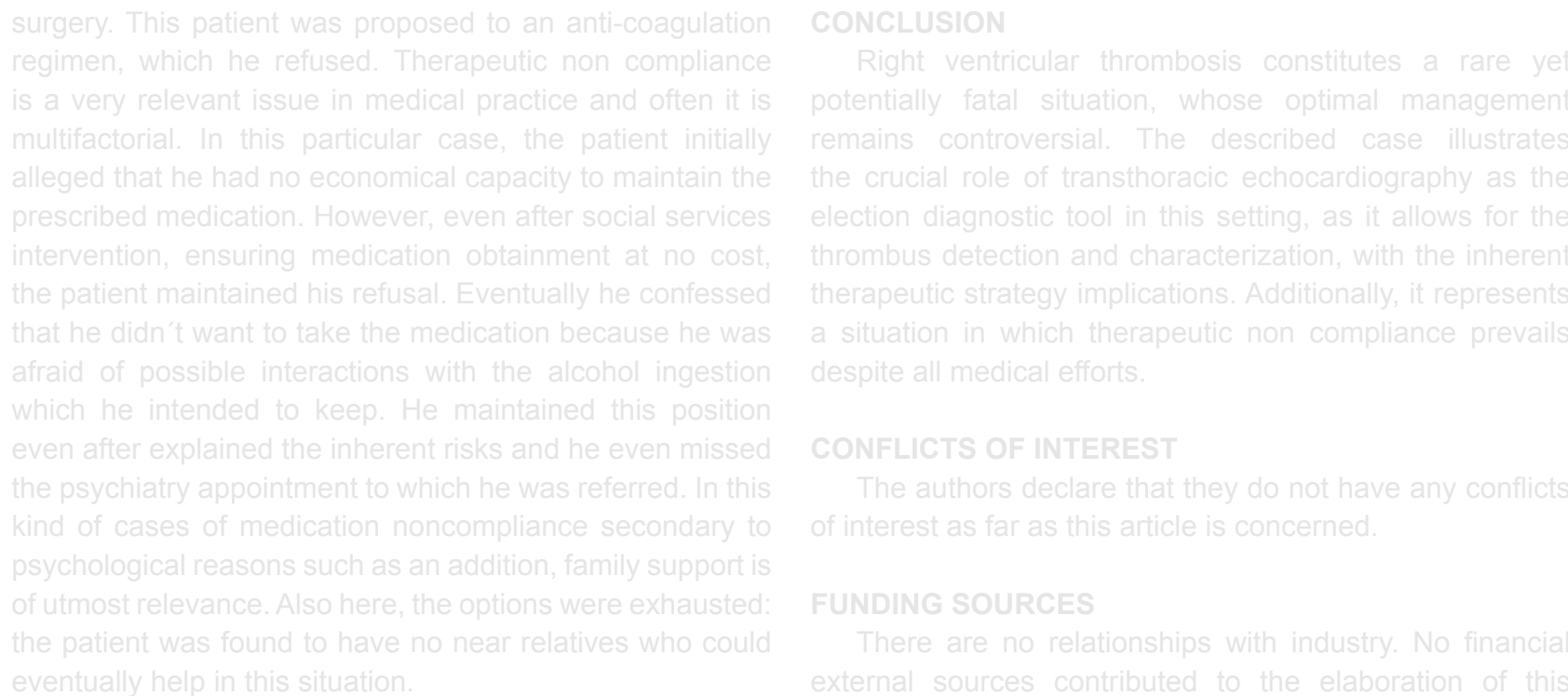

CONFLICTS OF INTEREST

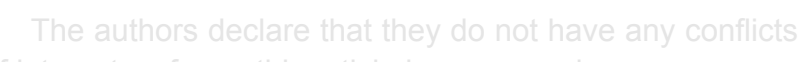

FUNDING SOURCES
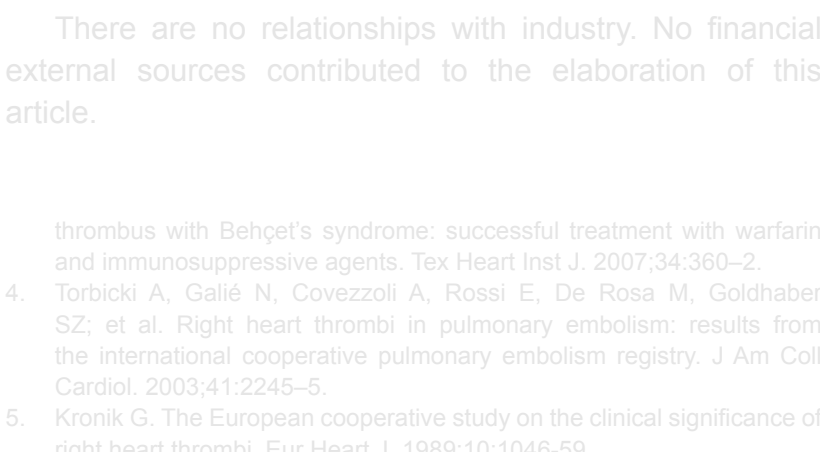

\title{
Secondary Progression is Not the Only Explanation
}

\author{
A Progressão Secundária Não é a Única Explicação
}

\author{
Filipe PALAVRA ${ }^{1}$, Carmen TUR ${ }^{1}$, Mar TINTORÉ ${ }^{1}$, Àlex ROVIRA², Xavier MONTALBAN ${ }^{1}$
}

Acta Med Port 2014 May-Jun;27(3):393-396

\begin{abstract}
Multiple sclerosis is an inflammatory demyelinating disorder of the central nervous system. Its presentation is variable and its course and prognosis are unpredictable. Approximately $85 \%$ of individuals present a relapsing-remitting form of the disease, but some patients may evolve into a progressive course, accumulating irreversible neurological disability, defining its secondary progressive phase. Despite all the advances that had been reached in terms of diagnosis, many decisions are still taken based only on pure clinical skills. We present the case of a patient that, after being diagnosed with a clinically isolated syndrome many years ago, seemed to be entering in a secondary progressive course, developing a clinical picture dominated by a progressive gait disturbance. Nevertheless, multiple sclerosis heterogeneity asks for some clinical expertise, in order to exclude all other possible causes for patients' complaints. Here we present an important red flag in the differential diagnosis of secondary progressive multiple sclerosis.
\end{abstract}

Keywords: Magnetic Resonance Imaging; Multiple Sclerosis, Chronic Progressive; Meningioma.

\section{RESUMO}

A esclerose múltipla é uma doença inflamatória e desmielinizante do sistema nervoso central. Tem apresentação variável e os respectivos curso clínico e prognóstico são heterogéneos. Cerca de $85 \%$ dos doentes apresentam uma evolução em surto e remissão, mas alguns podem assumir posteriormente um curso progressivo, com acumulação irreversível de incapacidade, definindo a forma secundariamente progressiva da doença. Apesar de todos os avanços conseguidos em termos de diagnóstico, muitas decisões práticas continuam a ser baseadas em aspectos puramente clínicos. Apresentamos o caso de uma doente que, depois do diagnóstico de

1. Neurology-Neuroimmunology Department. Multiple Sclerosis Centre of Catalonia. Vall d'Hebron University Hospital. Barcelona. Spain.

2. Radiology Department. Magnetic Resonance Unit. Vall d'Hebron University Hospital. Barcelona. Spain.

Recebido: 10 de Julho de 2013 - Aceite: 23 de Agosto de 2013 | Copyright ( ) Ordem dos Médicos 2014 
um síndrome clínico isolado há vários anos, parecia entrar numa fase secundariamente progressiva, desenvolvendo um quadro clínico dominado por uma limitação progressiva da marcha. Mas a esclerose múltipla requer alguma experiência, no sentido de excluir os diagnósticos alternativos, que podem justificar as queixas dos doentes. Aqui apresentamos um importante alerta para o diagnóstico diferencial de esclerose múltipla secundariamente progressiva.

Palavras-chave: Ressonância Magnética; Esclerosis Múltipla Crónica Progressiva; Meningioma.

\section{INTRODUCTION}

For the neurologist in practice, knowledge about the natural history of multiple sclerosis (MS) that encompasses the overall course and prognosis is a prerequisite to the counselling of a patient who is given such a diagnosis. MS is among the best studied chronic medical illnesses in terms of natural history, but despite a wealth of information gained from large, population-based studies on clinical features predictive of future course and outcome, the ability to apply this knowledge to an individual patient to allow the establishment of a prognosis can be problematic.

There are several disease subtypes, widely accepted among the scientific community. The most frequent clinical phenotype is the relapsing-remitting MS, defined by the occurrence of relapses (episodes of acute or subacute neurological dysfunction lasting a minimum of 24 hours) with full recovery or with sequelae and residual deficit on recovery, but with no disease progression between relapses. Relapsing-remitting MS may evolve into a gradually progressive course and patients can, in this context, accumulate irreversible neurological disability, defining the secondary progressive form of the disease. Approximately $10-15 \%$ of the patients suffer from primary progressive MS, a distinctive clinical phenotype characterized by an insidious disease progression from onset, resulting in gradual accumulation of neurological disability, without relapses or remission. There is finally a progressive relapsing form, encompassing those patients who have a progressive disease from onset, but with superimposed relapses.

In the study by Myhr and colleagues, the probability of entering a progressive course after 20 years of disease was $57.5 \%$ for patients with relapsing-remitting onset. ${ }^{1}$ Similarly, $57.6 \%$ of patients with disease duration of 11 to 15 years in the Ontario relapsing-onset cohort developed a progressive course. ${ }^{2}$ In the Olmsted County 2001 study, patients remaining in the relapsing-remitting group had a favourable course, with fewer than $25 \%$ reaching an Expanded Disability Status Scale (EDSS) score of 3 after 20 years of disease..$^{3,4}$

Despite these epidemiological data, the question of disability progression in MS may not be so clear in daily clinical practice. The diagnosis of MS, including its secondary progressive form, requires the exclusion of other causes for neurological disability increase, even at the most disease-advanced stages. So, the answer to the question 'is clinical progression due to the entrance in the secondary progressive phase of the disease?' in a patient who shows a progressive neurological worsening after a long-term history of MS may not be so simple.

\section{CLINICAL CASE}

We present the case of a 55 year-old female diagnosed with a clinically isolated syndrome 12 years ago, which consisted of left face numbness and gait instability that lasted for several days, before she was seen by a neurologist. At that time, brain magnetic resonance imaging (MRI) revealed the presence of multiple lesions compatible with the diagnosis of a primary demyelinating disease of the central nervous system (CNS) and cerebrospinal fluid examination detected the presence of $\operatorname{lgG}$ oligoclonal bands. No other relevant findings were identified on the additional paraclinical tests performed.

No specific and long-term disease modifying treatment was initiated at the time of diagnosis and the patient entered a program of regular monitoring in our centre, presenting a baseline EDSS score of 1.0. She remained clinically stable, referring only sporadic complaints of fatigue. However, in March 2012, the patient came for a regular visit with complaints of walking difficulties over the last months. She had even fallen down a number of times in the street and required an orthopaedics intervention. To this progressive gait disturbance, other symptoms were also slowly added: painful muscular spasms in both inferior limbs, hyperesthesia of the right leg, frequent urinary urgency/ incontinence, and a subjective sensation of balance loss, with recent (but progressive) aggravation. EDSS score was 3.5 , at this moment.

This history of disability progression, over several months, raised the possibility that the demyelinating disease was changing its behaviour from an initial phase of clinical stability over several years to a secondary progressive course. Abrain and spinal cord MRI was performed, revealing not only the already known demyelinating lesions (without any gadolinium enhancement or a dramatic increase in their number), but also a homogeneous contrast-enhanced intradural-extramedullary dural-based mass lesion, at the level of T5, which compressed and anteriorly displaced the spinal cord. Based on these findings, a radiologic diagnosis of meningioma was suggested (Fig. 1).

Following this observation, the patient was referred for neurosurgical evaluation and was promptly intervened. The pathological study of the tumour confirmed the diagnosis of a grade I meningothelial meningioma (OMS classification). Some days after hospital discharge, the patient referred a subjective increase in gait stability. At present, she has restarted her regular follow-up visits and she is not receiving any immunomodulatory drug.

\section{DISCUSSION}

One of the paradoxes of MS is that the diagnosis can be 

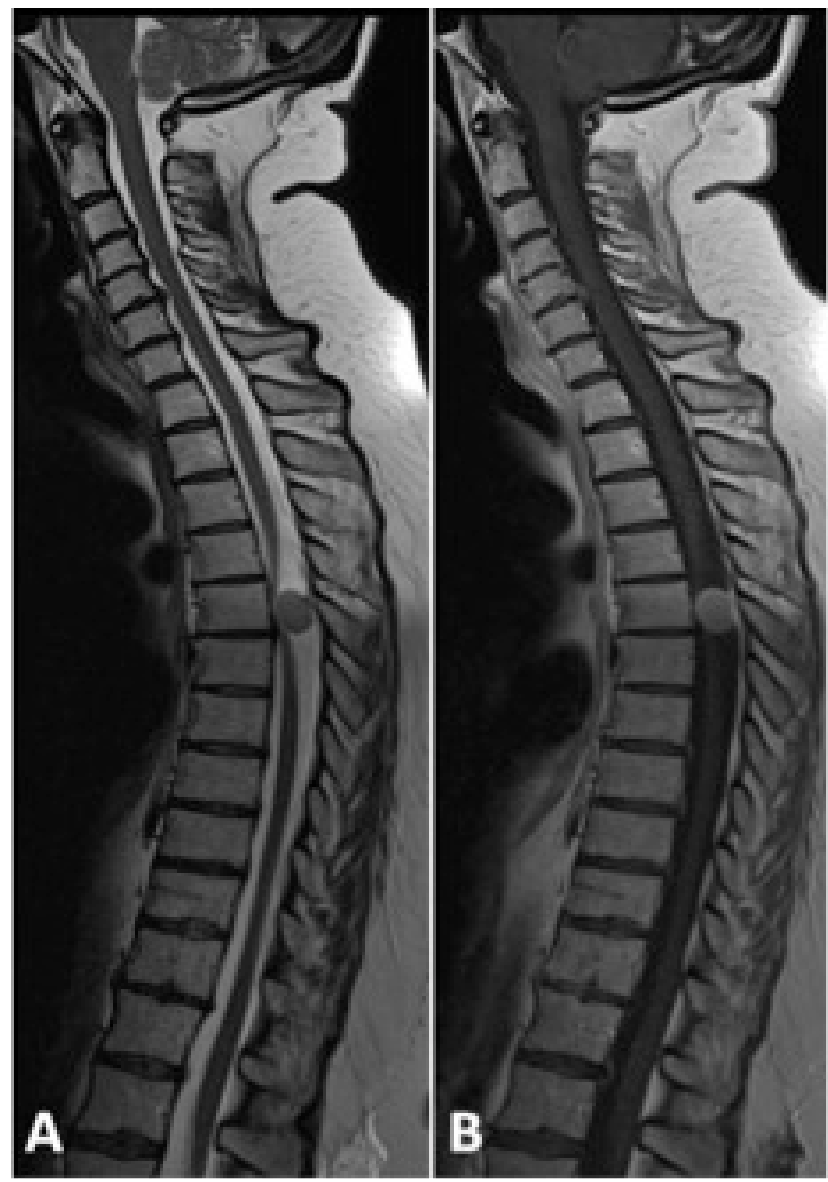

Figure 1 - Sagittal T2-weighted (A) and contrast-enhanced T1weighted (B) MRI of the spine. The images reveal an homogeneous and well defined contrast-enhanced intradural-extramedullary mass lesion, at the level of T5, which markedly compressed and anteriorly displaced the spinal cord, corresponding to a meningioma

relatively easy in some circumstances, but very challenging in other situations. This idea applies not only to the initial diagnosis of the disease, but still remains valid throughout its natural history, keeping the clinician always alert to the possibility of an alternative diagnosis to explain patient's complaints.

In our case, after 12 years, a very stable disease seemed to be transforming into a secondary progressive MS, in face of progressive neurological deficits evolving for several months. The coexistence of MS and a tumour that endangers the CNS may raise some difficulties in patient's evaluation, once the manifestations of the expansive process can be very similar to what is expected to occur in a secondary progressive disease, particularly when the compression occurs at spinal cord level. Degenerative spine disorders, with or without disc herniation, should also be included in this process of differential diagnosis, especially since the patient presented with a recent history of falls.

Meningiomas are the most common primary nonglial tumours with the possibility to compromise nervous system function. There is a female predilection with a ratio of about $2: 1$ and this kind of neoplasia is also associated with neurofibromatosis type $2 .{ }^{5}$ The higher incidence of CNS tumours (either derived from the parenchyma or from the meninges) in MS patients is controversial. The first description of such an association was done by Bosch ${ }^{6}$ in 1912 , but since then it has not been possible to establish a clear relationship. Some reports like the Danish Cancer Registry have suggested that the incidence of brain tumours in MS patients is higher than expected. ${ }^{7}$ On the other hand, more recently, it has been proposed that this phenomenon could correspond to a bias derived from the fact that MS patients generally undergo MRI scans with a much higher frequency than the general population. Thus, these patients would be more likely to be diagnosed with benign tumours than the rest of the population. This idea would be supported by the overrepresentation of benign tumours, amongst all the tumours that are diagnosed in patients with MS, in these studies. ${ }^{8,9}$

Another issue is the possible relationship between disease modifying drugs and the development of CNS cancer, although, in our case, the patient was not receiving any specific drug for $\mathrm{MS}$. Thus, a few cases have been described in the literature regarding this possible relationship. For example, in 2002, Batay and Al-Mefty ${ }^{10}$ described the possible relationship between MS and the development of a meningioma, showing the progression of the tumour during the treatment with interferon beta. They suggested and speculated that the long-term use of this medication might be responsible for the occurrence of lymphocytic infiltration and enlargement of meningiomas in MS patients. Nonetheless, in this paper, the authors only described two cases, so their message should be taken with caution. More recently, Drevelegas et al ${ }^{11}$ described the case of a patient presenting an intraventricular meningioma enlargement during interferon beta- $1 \mathrm{~b}$ treatment and suggested a possible relationship between the drug usage and the tumour growth, eventually mediated by platelet derived growth factor and transforming growth factor receptors in meningioma cells. However, the role of these receptors is surrounded by controversy in this context, because an inhibitory effect in meningioma cells was showed in vitro using interferon alpha. ${ }^{12}$ Gama et al $^{13}$ have described another case of an intracranial meningioma in a patient with MS treated with interferon beta-1a. They also speculated about the possible role of the drug on the tumour growth rate, which was not different from what is actually expected for meningiomas (normal range: $0.24-$ $1.0 \mathrm{~cm} /$ year). ${ }^{14}$ Nevertheless, considering that all these publications are only based on case reports and taking into account that data coming from clinical trials have shown no evidence that patients on first-line disease modifying drugs have a higher incidence of cancer, clinicians should be advised to take all this information very carefully.

Our illustrative case enhances the importance of differential diagnosis in MS, even at the advanced stages of the disease and when the diagnosis looks clearer than ever, according to its natural history. 


\section{CONFLICTS OF INTEREST}

The authors declare that they do not have any conflicts of interest as far as this article is concerned.

\section{FUNDING SOURCES}

Filipe Palavra reports no disclosures. Carmen Tur has received honoraria and support for travel from Merk Serono, Serono Foundation, Sanofi-Aventis, Teva and Novartis. Mar Tintoré received speaking honoraria and travel expenses for scientific meetings in the past with Bayer Schering Pharma, Biogen Idec, EMD Merck Serono, Genzyme, Novartis, Sanofi-Aventis and Teva Pharmaceuticals. Àlex Rovira serves on scientific advisory boards for NeuroTEC Pharma, AdvanceCell Bayer-Schering Pharma, Novartis Medical

\section{REFERENCES}

1. Myhr KM, Riise T, Vedeler C, Nortvedt MW, Grønning R, Midgard R, et al. Disability and prognosis in multiple sclerosis: demographic and clinical variables important for the ability to walk and awarding of disability pension. Mult Scler. 2001;7:59-65.

2. Weinshenker BG, Bass B, Rice GP, Noseworthy J, Carriere W, Baskerville $\mathrm{J}$, et al. The natural history of multiple sclerosis: a geographically based study. I. Clinical course and disability. Brain. 1989;112:133-46.

3. Kurtzke JF. Rating neurologic impairment in multiple sclerosis: an expanded disability status scale (EDSS). Neurology. 1983;33:1444-52.

4. Pittock SJ, Mayr WT, McClelland RL, Jorgensen NW, Weigand SD, Noseworthy $\mathrm{JH}$, et al. Disability profile of MS did not change over 10 years in a population-based prevalence cohort. Neurology. 2004;62:6016.

5. Atlas SW. Magnetic resonance imaging of the brain and spine. $3^{\text {rd }}$ edition. Lippincott Williams \& Wilkins. 2002:695-772.

6. Bosch G. Ein fall primarem Melanosarkom des Zentrlnervensystems bei multipler Sklerose. Zeit Med. 1912;33:917-22.

7. Moller H, Kneller RW, Boice JD, Olsen JH. Cancer incidence following hospitalization for multiple sclerosis in Denmark. Acta Neurol Scand. 1991;84:214-20.
Global Fingolimod Advisory Boards, and OLEA Medical, and on the editorial board of the American Journal of Neuroradiology and Neuroradiology, has received speaker honoraria from Bayer Schering Pharma, Sanofi-Aventis, Bracco, Merck-Serono, Teva Pharmaceutical Industries Ltd and Biogen Idec, OLEA Medical, receives research support from Bayer Schering Pharma and has research agreements with Siemens AG. Xavier Montalban has received speaking honoraria and travel expenses for scientific meetings, has been a steering committee member of clinical trials or participated in advisory boards of clinical trials in the past with Bayer Schering Pharma, Biogen Idec, EMD Merck Serono, Genentech, Genzyme, Novartis, Sanofi-Aventis, Teva Pharmaceuticals and Almirall.

8. Bahmanyar S, Montgomery SM, Hillert J, Ekbom A, Olsson T. Cancer risk among patients with multiple sclerosis and their parents. Neurology. 2009;72:1170-7

9. Hofer S, Linnebank M, Weller M, Bahmanyar S, Montgomery SM, Hillert $\mathrm{J}$, et al. Cancer risk among patients with multiple sclerosis and their parents. Neurology. 2010;74:614-5.

10. Batay F, Al-Mefty O. Growth dynamics of meningiomas in patients with multiple sclerosis treated with interferon: report of two cases. Acta Neurochir. 2002;144:365-8.

11. Drevelegas A, Xinou E, Karacostas D, Parissis D, Karkavelas G, Milonas I. Meningioma growth and interferon beta- $1 \mathrm{~b}$ treated multiple sclerosis: coincidence or relationship? Neuroradiology. 2005;47:516-9.

12. Zhang ZJ, Muhr C, Wang JL. Interferon-alpha inhibits the DNA synthesis induced by PDGF and EGF in cultured meningioma cells. Anticancer Res. 1996;16:1717-23.

13. Gama HP, da Rocha AJ, da Silva CJ, Mendes MF, Veiga JC, Lancellotti $\mathrm{CL}$, et al. Meningioma growth during interferon beta-1a for multiple sclerosis. Arq Neuropsiquiatr. 2008;66:402-4.

14. Herscovici Z, Rappaport Z, Sulkes J, Danaila L, Rubin G. Natural history of conservatively treated meningiomas. Neurology. 2004;63:1133-4. 
Filipe PALAVRA, Carmen TUR, Mar TINTORÉ, Àlex ROVIRA, Xavier MONTALBAN

\section{Secondary Progression is Not the Only Explanation \\ Acta Med Port 2014:27:393-396}

Publicado pela Acta Médica Portuguesa, a Revista Científica da Ordem dos Médicos

Av. Almirante Gago Coutinho, 151

1749-084 Lisboa, Portugal.

Tel: +351218428 215

E-mail: submissao@actamedicaportuguesa.com

www.actamedicaportuguesa.com

ISSN:0870-399X | e-ISSN: 1646-0758

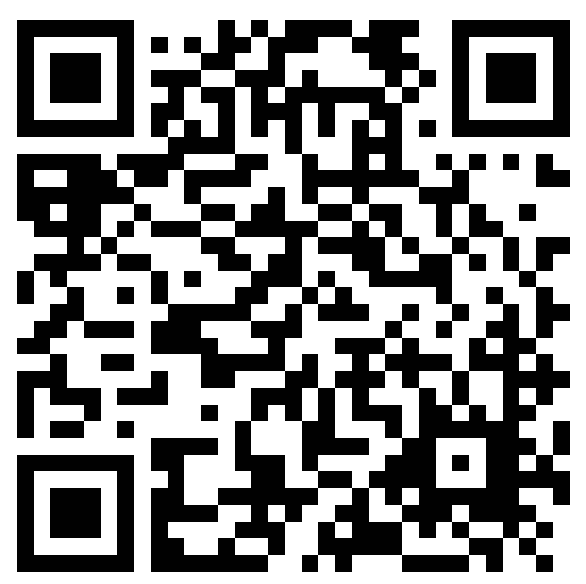

